\title{
PEMBENTUKAN MULTIKOMPONEN KRISTAL PIPERIN DAN KUERSETIN
}

\author{
Adhitya Jessica $^{\left.1^{*}\right)}$, Rifka Naura ${ }^{1}$, Uswatul Hasanah ${ }^{1}$, ,Erizal Zaini ${ }^{1}$, Lili Fitriani ${ }^{1}$ \\ ${ }^{I}$ Fakultas Farmasi Universitas Andalas \\ email : adhityajessica@phar.unand.ac.id
}

\begin{abstract}
The clinical use of piperine is still limited because it has low solubility in water. Quercetin is known as bioenhancer, increasing the bioavailability of other compounds. This study aims to improve the solubility of piperine by modifying it into a multicomponent form of crystals with quercetin. The formation of piperin-quercetin crystal multicomponent was carried out using the solvent drop grinding (SDG) method. Multicomponents are characterized by Differential Scanning Calorimetry (DSC), Powders X-Ray Diffraction (PXRD), and FTIR spectroscopy. Multicomponents evaluation was carried out by solubility test and the results were analyzed using HPLC. DSC thermogram shows the absence of new endothermic peaks that are significantly different from the two components. The multicomponent of piperin-quercetin X-ray diffraction pattern shows a diffractogram similar to the constituent components, which indicates no formation of the co-crystalline phase. Characterization using FTIR showed almost no shift in the peak absorption of piperin functional groups in crystal multicomponent. The solubility test was carried out on a pure piperine compound, the physical mixture of piperin-quercetin and multicomponent piperin-quercetin (1:1) made by the SDG method. The physical mixture and multicomponent piperin-quercetin made by the SDG method increased the solubility of piperine by 1.475 -fold and 1.389-fold when compared to pure piperine.
\end{abstract}

Keywords:piperine, quercetin, multicomponent crystal, solubility, HPLC

\begin{abstract}
ABSTRAK
Penggunaan klinis piperin masih terbatas karena memiliki kelarutan rendah di dalam air. Kuersetin dikenal sebagai bioenhancer yang dapat meningkatkan bioavailibilitas senyawa lain. Penelitian ini bertujuan untuk meningkatkan kelarutan piperin dengan memodifikasinya menjadi bentuk multikomponen kristal bersama kuersetin. Pembentukan multikomponen kristal piperinkuersetin dilakukan menggunakan metode solvent drop grinding (SDG). Multikomponen dikarakterisasi dengan Differential Scanning Calorimetry (DSC), Powders X-Ray Diffraction (PXRD) dan spektroskopi FTIR.Evaluasi multikomponen dilakukan dengan uji kelarutan dan hasilnya dianalisis menggunakan KCKT.Termogram DSC menunjukkan tidak adanya puncak endotermik baru yang berbeda nyata dari kedua komponen. Pola difraksi sinar-X multikomponen kristal piperin-kuersetin menunjukkan difraktogram yang serupa dengan komponen penyusun, yang mengindikasikan tidak terbentuknya fase kokristalin. Karakterisasi menggunakan FTIR menunjukkan hampir tidak ada pergeseran puncak serapan gugus fungsi piperin pada multikomponen kristal. Uji kelarutan dilakukan terhadap senyawa tunggal piperin, campuran fisik piperin-kuersetin dan multikomponen piperin-kuersetin (1:1) yang dibuat dengan metode SDG. Campuran fisik dan multikomponen piperin-kuersetin yang dibuat dengan metode SDG
\end{abstract}


meningkatkan kelarutan piperin sebesar 1,475 kali lipat dan 1,389 kali lipat jika dibandingkan dengan piperin murni.

Kata kunci:piperin, kuersetin, multikomponen kristal, kelarutan, KCKT

\section{PENDAHULUAN}

Piperin merupakan alkaloid utama yang diperoleh dari lada hitam dan memiliki aktivitas farmakologi yang beragam, yaitu sebagai antioksidan, antiinflamasi, antipiretik, antijamur, antidiare, antidepresan, antitiroid, antimutagen, antitumor, analgetik, hepatoprotektif, antihipertensi dan aktivitas farmakologi lainnya (Azajuddin et al., 2014). Piperin juga menunjukkan aktivitas sebagai bioenhancer yang dapat meningkatkan bioavailibilitas berbagai senyawa di dalam tubuh (Atal, Dubey and Singh, 1985; Khajuria, Zutshi and Bedi, 1998; Shaikh et al., 2009; Kesarwani and Gupta, 2013; Azajuddin et al., 2014).

Penggunaan klinis piperin masih terbatas karena memiliki kelarutan yang rendah $(1 \mathrm{~g} / 25 \mathrm{~L})$ dalam air (Kumar et al., 2018). Kelarutan yang rendah mengakibatkan rendahnya bioavailibilitas piperin dalam plasma sehingga harus diberikan dengan dosis terapi yang tinggi dan dapat berisiko toksik terhadap sistem reproduksi dan sistem saraf (Veerareddyet al., 2004; Pachauriet al., 2015).

Berapa penelitian telah dilakukan untuk meningkatkan kelarutan piperin dalam air, seperti pembentukan dispersi padat dan pembentukan kompleks inklusi (Thenmozhi \& Yoo, 2017; Ezawa et al., 2018). Pembentukan dispersi nanopartikel lipid padat piperin yang berbasis gliseril monostearat dengan menggunakan metode emulsifikasi lebur juga telah dilakukan (Bhalekar et al., 2017).

Kuersetin adalah salah satu metabolit sekunder golongan flavonoid yang dapat ditemukan pada cranberry, bawang bombai, apel, paprika, blueberry, dan anggur. Kuersetin memiliki aktivitas antioksidan yang tinggi dan memiliki aktivitas farmakologis sebagai obat antikanker (Miltonprabu, 2019). Selain itu, kuersetin juga memiliki efek antiobesitas, antivirus, cardioprotective, antiinflamasi dan antibakteri, dan (Ramos et al., 2006; Boots et al., 2008; Zandi et al., 2011; Miltonprabu, 2019).

Beberapa penelitian telah menunjukkan efek bioenhancer kuersetin terhadap piperin. Pemberian piperin dan kuersetin dalam bentuk ko-administrasi dengan rute per-oral memperlihatkan poteniasi efek protektif piperin terhadap chronic unpredictable stress (CUS) pada mencit yang diinduksi dengan gangguan kognitif (Rinwaet al., 2012).

Penelitian mengenai aktivitas bioenhancer dan antioksidan dari piperin dan kuersetin juga telah dilakukan sebelumnya. Dari penelitian yang dilakukan oleh Mehta (2012), piperin dan kuersetin yang dikombinasikan dengan kurkumin dalam bentuk suspensi memperlihatkan peningkatan bioavailibilitas dan peningkatan aktivitas antioksidan sebanyak 50\% Ketika diberikan pada mencit secara peroral (Mehta et al., 2012).

Pembentukan kokristal piperin untuk peningkatan kelarutan telah dilakukan pada penelitian sebelumnya. Piperin dibentuk menjadi kokristal dengan asam nikotinat. Kokristal piperin dan asam nikotinat memiliki kelarutan yang lebih baik dari piperin murni. Berdasarkan karakterisasi multikomponen kristal piperin-asam nikotinat, diperoleh pola difraksi sinar-X berupa puncak difraksi baru. Analisa termal termogram DSC menunjukkan puncak endotermik pada $126,117^{\circ} \mathrm{C}$. Uji kelarutan menunjukkan peningkatan kelarutan piperin 1,5 kali lipat dibandingkan piperin murni dan profil disolusi piperin menunjukkan peningkatan signifikan dibandingkan piperin murni, sekitar 2,5 kali lipat (Sari et al., 2019).

Dalam penelitian ini upaya peningkatan aktivitas farmakologi piperin dan kuersetin dilakukan dengan membuat piperin dan kuersetin menjadi bentuk multikomponen kristal. Multikomponen kristal adalah sediaan kristalin dengan struktur homogen yang mengandung dua atau lebih bahan dalam jumlah stoikiometri yang tepat (Theses \& Dawn Marie Clarke, 2012). Pembuatan multikomponen kristal dari bahan yang memiliki kelarutan rendah dalam air berpotensi 
memberikan peningkatan laju disolusi, kelarutan, bioavailibilitas dan stabilitas fisika (Lu \& Rohani, 2009).

Peningkatan kelarutan piperin dapat dikembangkan lebih lanjut menjadi sediaan obat. Multikomponen piperin-kuersetin dirancang dengan berbagai perbandingan ekuimol berbeda untuk mendapatkan perbandingan yang tepat. Hasil multikomponen kristal dikarakterisasi menggunakan metode karakterisasi kristal yaitu, Differential Scanning Calorimetry (DSC), Powders X-Ray Diffraction (PXRD) dan spektroskopi FTIR. Uji kelarutan juga akan dilakukan dalam studi ini untuk melihat pengaruh pembentukan multikomponen kristal terhadap sifat fisikokimia piperin.

\section{METODE}

Alat dan Bahan

Bahan yang digunakan antara lain: lada hitam, metanol, etil asetat, Piperin (Tokyo Chemical Industry, Japan), Kuersetin (Tokyo Chemical Industry, Japan), metanol pro high performence liquid chromatography (Merck, Germany), etanol pro analysis (Merck, Germany), aqua pro injection (PT. Ikapharmindo Putramas, Indonesia), aquades (Laboratorium Kimia Universitas Andalas, Indonesia).

Alat yang digunakan adalah Differential scanning calorimetry (Shimadzu DSC-60 Plus, Jepang), difraktometer sinar-X serbuk (Rigaku tipe RINT-2500, Jepang), kertas saring Whatman ukuran $0,45 \mu \mathrm{m}$, mortir, stamper, timbangan digital (Shimadzu-AUX 220, Jepang), Spektrofotometer IR (Thermo Scientific, USA), High Performance Liquid Chromatography (KCKT) dengan detektor DAD UV-VIS (Shimadzu AUX 220, Jepang), Elma Ultrasonic Cleaner $\mathrm{P} 120 \mathrm{H}$ (Sonikator), alumunium foil, desikator, dan alat gelas standar laboratorium lainnya

\section{Metode}

1. Isolasi Piperin.

Sebanyak $2 \mathrm{~kg}$ lada hitam diekstraksi dengan metode maserasi menggunakan pelarut metanol. Maserat kemudian dikentalkan dengan rotary evaporator. Maserat kental lalu didiamkan hingga terbentuk kristal pada bagian bawah permukaan wadah. Kristal yang terbentuk selanjutnya direskristalisasi menggunakan etil asetat sehingga diperoleh kristal murni. Kristal murni diuji dengan KLT menggunakan pembanding piperin (TCI) untuk melihat tingkat kemurniannya. Kemurnian ditandai dengan didapatnya satu noda.

\section{Pembuatan Campuran Fisik Piperin-Kuersetin}

Campuran fisik piperin-kuersetin dibuat dengan menimbang dan mencampurkan piperin dan kuersetin dengan perbandingan 1:1 ekuimol (0,285 g: 0,302 g).Campuran kemudian disimpan pada desikator dan selanjutnya dikarakterisasi dengan Differential Scanning Calorimetry (DSC) dan Fourier Transform InfraRed (FTIR).

3. Pembuatan Multikomponen Kristal Piperin-Kuersetin dengan Metode Solvent Drop Grinding Kuersetin dan piperin dengan perbandingan 1:1 ekuimol $(0,302 \mathrm{~g}: 0,285 \mathrm{~g})$ digerus secara konstan selama 10 menit sambil diteteskan metanol sebanyak $0,145 \mathrm{~mL}$. Hasil yang didapat disimpan pada desikator dan selanjutnya dikarakterisasi dengan Differential Scanning Calorimetry (DSC) dan Powder X-Ray Diffraction (PXRD).

\section{Evaluasi Multikomponen Kristal Piperin-Kuersetin}

Analisis termal sampel dilakukan menggunakan DSC yang telah dikalibrasi suhu dengan Indium. Sejumlah 2-5 mg sampel diletakkan pada pan aluminium tertutup. DSC kemudian diprogram untuk rentang suhu $30^{\circ} \mathrm{C}-300^{\circ} \mathrm{C}$ dengan kecepatan pemanasan $10^{\circ} \mathrm{C}$ per menit. Analisis dilakukan terhadap kuersetin, piperin, dan multikomponen kristalpiperin-kuersetin. 
Analisis difraksi sinar-X sampel dilakukan pada suhu ruang dengan difraktometer rigaku tipe RINT-2500. Pengukuran dilakukan pada kondisi: target logam $\mathrm{Cu}$, filter $\mathrm{K} \alpha$, voltase $40 \mathrm{kV}$, arus 40 $\mathrm{mA}$, dan analisis dilakukan pada rentang 2 theta $50-500$. Sampel diletakkan pada sampel holder (kaca) dan diratakan untuk mencegah orientasi partikel selama penyiapan sampel. Analisis dilakukan terhadap sampel kuersetin, piperin, dan multikomponen kristalpiperin-kuersetin.

Analisis Fourier Transform Infrared (FTIR) dilakukan dengan mendispersikan sampel pada kristal ATR hingga menutupi semua permukaan. Spektrum serapan direkam pada bilangan gelombang 4000-600 cm-1. Analisis dilakukan terhadap sampel kuersetin, piperin, dan multikomponen kristalpiperin-kuersetin.

\section{Uji Kelarutan}

Uji kelarutan dilakukan pada piperin, campuran fisik Piperin-Kuersetin (1:1), dan solvent-drop grinding (SDG) piperin-kuersetin (1:1). Masing-masing sampel ditimbang setara dengan $10 \mathrm{mg}$ piperin, kemudian dimasukkan ke erlenmeyer $100 \mathrm{~mL}$ dan volume digenapkan dengan $100 \mathrm{~mL}$ air suling bebas $\mathrm{CO} 2$. Setelah disonikator selama 30 menit, sampel disaring dengan kertas Whatman $0,45 \mu \mathrm{m}$. Filtrat yang diperoleh dianalisis dengan KCKT.Analisis dilakukan dengan tiga kali pengulangan.

\section{Analisis Data}

Analisa data yang didapat dilakukan dengan menggunakan perhitungan ANOVA satu arah dengan program SPSS 22. Data hasil uji kelarutan piperin murni dibandingkan dengan campuran fisik piperin-kuersetin dan multikomponen piperin-kuersetin dengan teknik solvent-drop grinding.

\section{Hasil dan Pembahasan}

Piperin yang didapat dari proses isolasi adalah sebanyak 76,073 g dengan rendemen $3,804 \%$. Piperin yang diperoleh (Gambar 1) diuji dengan KLT dengan pembanding piperin (TCI). Eluen yang digunakan adalah heksan:etil asetat (7:3). Piperin hasil isolasi berbentuk kristal jarum kekuningan. Nilai Rf piperin isolat sama dengan piperin pembanding yakni 0,39 (Gambar 2).

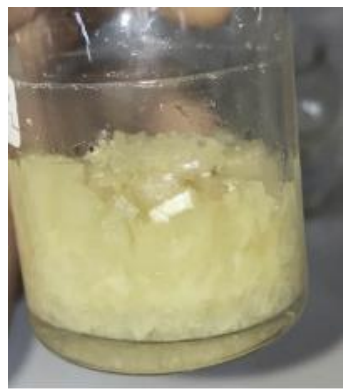

Gambar 1. Piperin hasil isolasi 


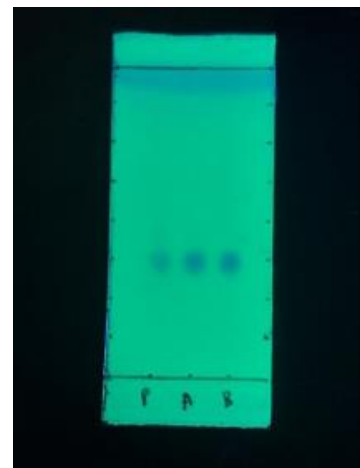

Gambar 2. Uji KLT piperin hasil isolat (A dan B) dibandingkan dengan piperin pembanding $(P)$

Hasil analisis XRD terhadap piperin, kuersetin, dan multikomponen kristal piperin:kuersetin 1:2, 2:1 dan 1:2 dengan metode solvent-drop grinding (SDG) dapat dilihat pada Gambar 3. Perbandingan puncak intensitas dapat dilihat pada Tabel 1.

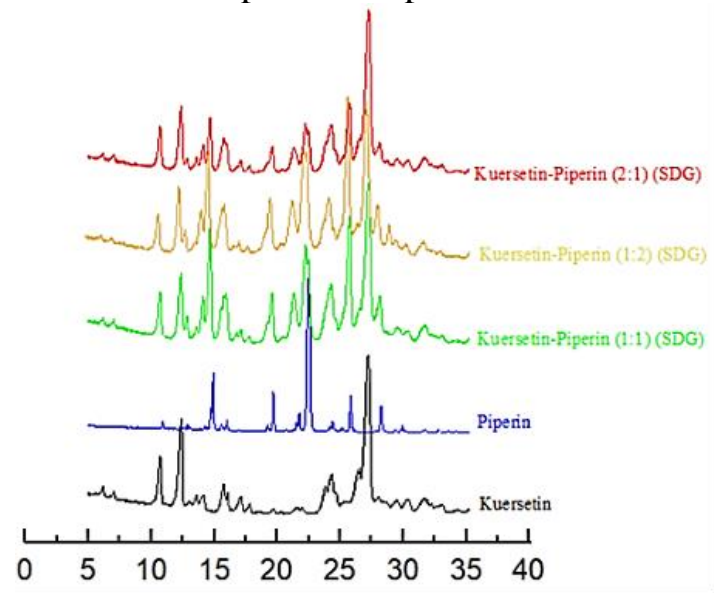

Gambar 3. Difraktogram piperin, kuersetin, SDG Piperin-Kuersetin (1:1), SDG Piperin-Kuersetin (2:1), dan SDG Piperin-Kuersetin (1:2).

Tabel I. Perbandingan difraktogram piperin, kuersetin, SDG Piperin-Kuersetin (1:1), SDG Piperin-Kuersetin (2:1), dan SDG Piperin-Kuersetin (1:2).

\begin{tabular}{rrrrrr}
\hline $\begin{array}{c}\text { Puncak } \\
\text { Difraksi } \\
(\mathbf{X})\end{array}$ & Piperin & Kuersetin & $\begin{array}{c}\text { SDG Pip-Kuer } \\
(1: 1)\end{array}$ & $\begin{array}{c}\text { SDG Pip-Kuer } \\
(2: 1)\end{array}$ & $\begin{array}{c}\text { SDG Pip-Kuer } \\
(1: 2)\end{array}$ \\
\cline { 2 - 6 } & & & 2369,44 & 3462,66 & 2181,57 \\
\hline $\mathbf{1 0 , 7 0 5}$ & 834,63 & 3077,18 & 3097,63 & 4638,02 & 3181,55 \\
\hline $\mathbf{1 2 , 3 7 5}$ & 745,56 & 4933,22 & 1452,80 & 1428,26 & 1451,58 \\
\hline $\mathbf{1 2 , 8 3 5}$ & 1409,49 & 751,48 & 2208,39 & 2282,70 & 2204,24 \\
\hline $\mathbf{1 4 , 1 0 5}$ & 745,63 & 1171,55 & 4873,62 & 3952,29 & 4830,44 \\
\hline $\mathbf{1 4 , 6 9 5}$ & 8162,11 & 406,30 & 2325,24 & 2315,38 & 2449,89 \\
\hline $\mathbf{1 5 , 8 8 5}$ & 793,93 & 1742,03 & 2325,96 & 2136,86 & 2800,24 \\
\hline $\mathbf{1 9 , 6 0 5}$ & 5760,67 & 469,23 & & &
\end{tabular}


JOPS (Journal Of Pharmacy and Science)

Vol.4, No.2, Bulan Juni 2021, Hal. 1-11

p-ISSN: 2622-9919; e-ISSN: 2615-1006

\begin{tabular}{rrrccr}
\hline $\mathbf{2 1 , 2 9 5}$ & 1682,04 & 456,94 & 2332,71 & 2114,42 & 2610,93 \\
\hline $\mathbf{2 2 , 2 4 5}$ & 21578,94 & 351,59 & 4199,11 & 3518,62 & 4671,24 \\
\hline $\mathbf{2 4 , 2 9 5}$ & 1743,48 & 2201,54 & 2673,13 & 3504,01 & 2775,38 \\
\hline $\mathbf{2 5 , 7 4 5}$ & 5129,94 & 830,66 & 5263,59 & 4687,81 & 6650,22 \\
\hline $\mathbf{2 7 , 2 4 5}$ & 394,03 & 8021,49 & 6553,93 & 10562,37 & 6517,09 \\
\hline $\mathbf{2 8 , 1 7 5}$ & 3847,71 & 903,84 & 2232,32 & 2315,40 & 2532,96 \\
\hline
\end{tabular}

$X$-Ray difraction memanfaatkan interaksi antara sinar-x dengan atom yang tersusun dalam sistem kristal(Setiabudi, Hardian and Mudzakir, 2012).X-Ray difraction dapat digunakan untuk melihat terbentuknya kokristal atau tidak. Pada hasil X-Ray Powder Diffraction (XRPD) terlihat pola puncak spesifik yang berbeda antara kokristal dengan komponentunggal penyusun kokristal(Lihat gambar 4) (Yusuf et al., 2013).

Hasil analisis XRD terhadap SDG piperin-kuersetin dengan perbandingan 1:1, 2:1, dan 1:2 menunjukkan bahwa semua puncak yang muncul merupakan puncak interferensi spesifik sampel tunggal piperin dan kuersetin. Tidak terdapat puncak baru pada sudut difraksi $2 \theta$ dari sampel SDG piperin-kuersetin. Hal ini menunjukkan bahwa penggabungan piperin-kuersetin dengan metode solvent-drop grinding tidak membentuk fase kristalin baru. Walaupun tidak terbentuk fase kristalin baru, multikomponen kristal menunjukkan adanya perbedaan derajat kristalinitas terhadap senyawa murni dengan adanya penurunan intensitas pola difraksi sinar-X.

Hasil analisis DSC dari sampel piperin, kuersetin, campuran fisik dan multikomponen kristal piperin:kuersetin 1:2, 2:1 dan 1:2 dengan metode solvent-drop grinding (SDG) dapat dilihat pada Gambar 4. Perbandingan titik lebur dan energi dapat dilihat pada Tabel 2.

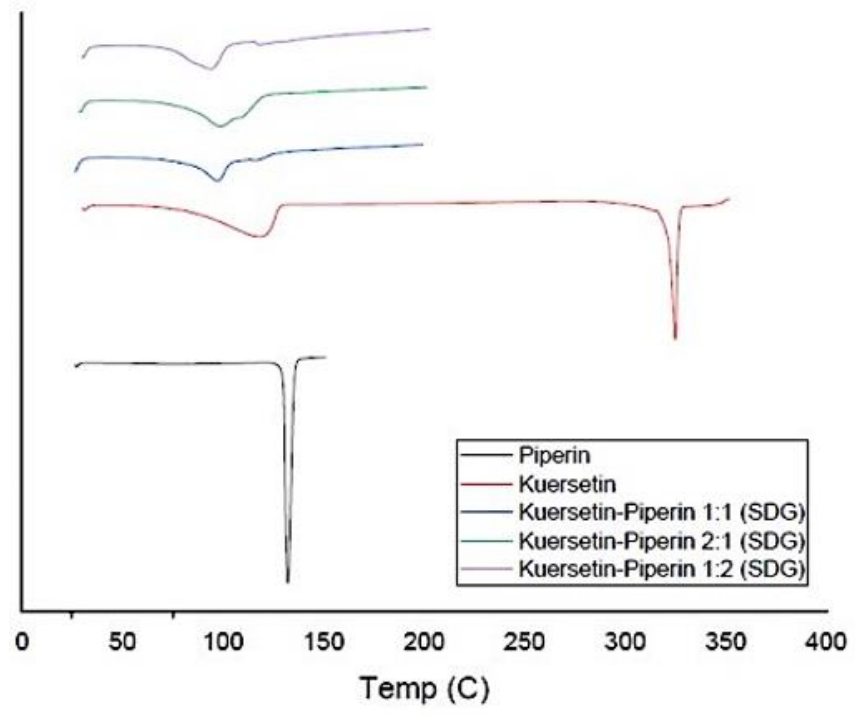

Gambar 4. Perbandingan termogram piperin, kuersetin, SDG PiperinKuersetin (1:1), SDG Piperin-Kuersetin (2:1), dan SDG PiperinKuersetin (1:2). 
Tabel II. Perbandingan termogram piperin, kuersetin, CF Piperin-Kuersetin (1:1), SDG Piperin-Kuersetin (1:1), SDG Piperin-Kuersetin (2:1), dan SDG Piperin-Kuersetin (1:2).

\begin{tabular}{lrr}
\hline \multicolumn{1}{c}{ Sampel } & Titik Lebur $\left({ }^{\circ} \mathbf{C}\right)(\mathbf{X})$ & Energi (mJ) (Y) \\
\hline Piperin & 132,19 & 293,36 \\
\hline Kuersetin & 324,77 & 241,08 \\
\hline CF Pip-Kuer (1:1) & 115,59 & 600,14 \\
\hline SDG Pip-Kuer (1:1) & 97,26 & 257,55 \\
\hline SDG Pip-Kuer (1:2) & 98,77 & 368,32 \\
\hline SDG Pip-Kuer (2:1) & 93,75 & 207,91
\end{tabular}

Analisa termal diferensial merupakan teknik dimana suhu sampel dibandingkan dengan material acuan (reference) yang inert selama terjadinya perubahan suhu lingkungan (furnace) secara terprogram. Pada pemanasan sampel, suhu sampel dan pembanding akan sama apabila tidak terjadi peristiwa termal seperti pelelehan, dekomposisi atau perubahan struktur kristal pada sampel. Apabila terjadi beberapa peristiwa termal tersebut, suhu dari sampel dapat berada di bawah (apabila perubahanbersifat endoterm) atau di atas (apabila perubahan bersifat eksoterm) suhu pembanding (lihat gambar 3). Perbedaan ini yang diukur dan menjadi dasar analisis diferensial termal (Setiabudiet al., 2012).

Hasil pemeriksaan DSC terhadap sampel campuran fisik piperin-kuersetin (1:1) memperlihatkan bahwa zona kristalin piperin mengalami overlapping dengan zona kristalin air pada kuersetin hidrat, akan tetapi tidak memberikan puncak lebur baru. Sampel SDG PiperinKuersetin (1:1), SDG Piperin-Kuersetin (2:1), dan SDG Piperin-Kuersetin (1:2) juga tidak memperlihatkan adanya puncak lebur baru, namun keberadaan air pada kuersetin hidrat mengakibatkan puncak lebur piperin terjadi pada suhu yang lebih rendah. Tidak adanya puncak lebur baru menunjukkan bahwa campuran fisik piperin-kuersetin dan multikomponen kristal piperin-kuersetin menggunakan metode solvent drop grinding (SDG) tidak memberikan interaksi antarmolekul yang merubah sifat fisikokimia senyawa. Pada pemanasan yang tinggi kuersetin dalam campuran kemungkinan tidak stabil sehingga kuersetin terurai dan ditunjukkan oleh adanya puncak tidak beraturan pada suhu diatas $250^{\circ}$.

Hasil analisis FTIR piperin, kuersetin, campuran fisik dan multikomponen kristal piperin:kuersetin 1:1 dengan metode solvent-drop grinding dapat dilihat pada Gambar 5. Perbandingan puncak intensitas dapat dilihat pada Tabel 3.

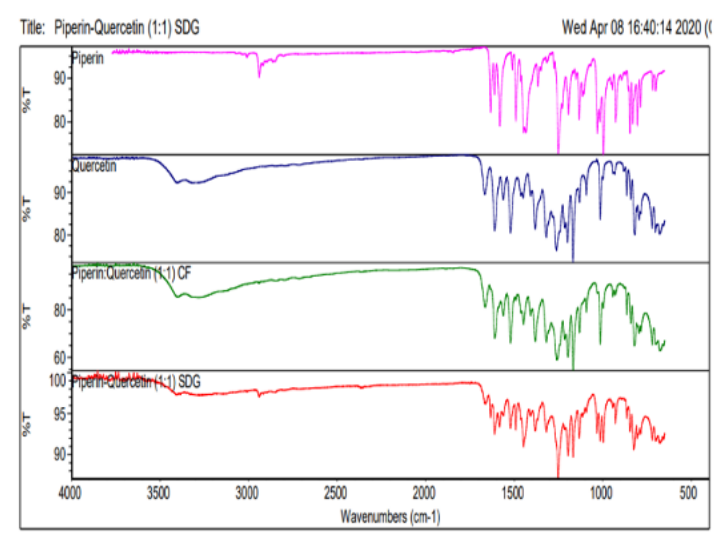

Gambar 5. Spektrum FTIR piperin, kuersetin, CF Piperin-Kuersetin (1:1) dan SDG Piperin-Kuersetin (1:1). 
Tabel III. Perbandingan spektrum FTIR piperin, kuersetin, CF Piperin-Kuersetin (1:1) dan SDG PiperinKuersetin $(1: 1)$

\begin{tabular}{|c|c|c|c|c|c|}
\hline \multirow[t]{2}{*}{ Gugus Fungsi } & \multirow{2}{*}{$\begin{array}{l}\text { Rentang Bilangan } \\
\text { Gelombang }\left(\mathrm{cm}^{-1}\right)\end{array}$} & \multicolumn{4}{|c|}{ Bilangan Gelombang $\left(\mathrm{cm}^{-1}\right)$} \\
\hline & & Piperin & Kuersetin & $\begin{array}{l}\text { CF Pip-Kuer } \\
(1: 1)\end{array}$ & $\begin{array}{l}\text { SDG Pip-Kuer } \\
(1: 1)\end{array}$ \\
\hline O-H & $3200-3550$ & - & 3311,80 & 3282,43 & 3277,81 \\
\hline O-H (Fenol) & $1310-1390$ & - & 1318,72 & 1317,94 & 1317,90 \\
\hline $\mathrm{C}=\mathrm{O}($ Keton $)$ & $1540-1870$ & 1633,12 & 1610,25 & 1609,50 & 1610,57 \\
\hline $\mathrm{C}-\mathrm{N}$ & $1180-1360$ & 1251,10 & - & 1258,58 & 1252,09 \\
\hline C-O (Eter) & $1050-1300$ & 1133,24 & 1168,40 & 1167,57 & 1167,66 \\
\hline $\mathrm{C}=\mathrm{C}$ (Alkena) & $675-995$ & 846,37 & - & 819,97 & 824,36 \\
\hline
\end{tabular}

Spektroskopi inframerah merupakan teknik yang dapat mengidentifikasi senyawa dengan melihat interaksi molekul dengan gelombang elektromagnetik pada rentang inframerah mulai dari 4000 hingga $400 \mathrm{~cm}^{-1}$. Jenis ikatan kimia yang terdapat dalam sampel dapat diketahui dengan melihat spektrum serapan pada panjang gelombang radiasi inframerah yang menyebabkan transisi vibrasi gugus fungsi tertentu (Lihat gambar 5 (Azizet al., 2015) dan Tabel 1) (Müller, 1994). Fourier Transform Infrared (FTIR) merupakan perkembangan dari spektroskopi inframerah.Teknik ini dapat menunjukkan gugus fungsi yang bertanggung jawab pada perubahan kimia atau interaksi supramolekul nonkovalen. Hal ini dapat dilihat dari variasi bentuk puncak dan intensitas spektrum serapan yang dihasilkan (Kumar et al., 2019).

Pemeriksaan FTIR dan uji kelarutan hanya dilakukan terhadap CF Piperin-Kuersetin (1:1) dan SDG Piperin-Kuersetin (1:1). SDG Piperin-Kuersetin (1:1) dipilih karena hanya perbandingan piperin-kuersetin 1:1 yang menunjukkan puncak lebih tajam dibandingkan SDG piperin-kuersetin 2:1 dan 1:2.

Analisis Fourier Transform Infrared (FTIR) dilakukan untuk mendukung analisis XRD dan DSC. Analisis ini dapat melihat ada atau tidaknya pergeseran spektrum yang terbentuk dari multikomponen piperin-kuersetin yang didapat dari metode solvent-drop grinding dengan perbandingan piperin:kuersetin 1:1, 2:1 dan 1:2. Ikatan tersebut dapat mengalami stretching (peregangan) ataupun bonding (pengerutan) yang dapat mempengaruhi sifat fisikokimia senyawa, salah satunya kelarutan.

Hasil analisis spektroskopi FTIR menunjukkan puncak spektrum piperin pada bilangan gelombang $1633,12 \mathrm{~cm}^{-1} ; 1251,10 \mathrm{~cm}^{-1} ; 1133,24 \mathrm{~cm}^{-1}$ dan $846,37 \mathrm{~cm}^{-1}$ yang memperlihatkan adanya gugus $\mathrm{C}=\mathrm{O}$, gugus $\mathrm{C}-\mathrm{N}$, gugus $\mathrm{C}-\mathrm{O}$ dan gugus $\mathrm{C}=\mathrm{N}$ pada piperin. Sedangkan puncak spektrum kuersetin pada bilangan gelombang $3311,80 \mathrm{~cm}^{-1} ; 1318,72 \mathrm{~cm}^{-1} ; 1610,25 \mathrm{~cm}^{-1}$ dan $1168,40 \mathrm{~cm}^{-1}$ menunjukkan adanya gugus $\mathrm{O}-\mathrm{H}, \mathrm{O}-\mathrm{H}$ (fenol), $\mathrm{C}=\mathrm{O}$ dan gugus $\mathrm{C}-\mathrm{O}$ pada kuersetin. Setelah dilakukan pembentukan campuran fisik (CF) dan solvent-drop grinding (SDG) piperinkuersetin 1:1, terdapat puncak spektrum yang menunjukkan pergeseran, akan tetapi pergeseran ini masih berada dalam rentang bilangan gelombang seharusnya yang dapat dilihat pada Tabel 3 .

Hasil uji kelarutan dari larutan jenuh campuran fisik (CF) piperin-kuersetin (1:1) dan solvent-drop grinding (SDG) piperin-kuersetin (1:1) di dalam air suling bebas $\mathrm{CO} 2$ masing-masing memperlihatkan peningkatan kelarutan sebesar 1,475 dan 1,389 kali dari kelarutan larutan jenuh piperin tunggal dalam air suling bebas $\mathrm{CO} 2$ (Tabel 4). 
Tabel IV.Hasil peningkatan kelarutan campuran fisik (CF) Piperin-Kuersetin (1:1), dan solvent-drop grinding (SDG) piperin-Kuersetin (1:1) dibandingkan dengan larutan jenuh piperin dalam air suling bebas $\mathrm{CO}_{2}$

\begin{tabular}{lcr}
\hline Sampel & $\begin{array}{c}\text { Konsentrasi rata-rata } \\
(\mathbf{m g} / \mathbf{1 0 0} \mathbf{~} \mathbf{L}) \pm \mathbf{S D}\end{array}$ & $\begin{array}{c}\text { Peningkatan } \\
\text { Kelarutan }\end{array}$ \\
\hline Piperin & $1,906 \pm 0,195$ & - \\
\hline CF & $2,812 \pm 0,157$ & 1,475 \\
\hline SDG & $2,648 \pm 0,188$ & 1,389 \\
\hline
\end{tabular}

Hasil uji kelarutan dalam air suling bebas $\mathrm{CO}_{2}$ dari larutan jenuh campuran fisik (CF) piperin-kuersetin (1:1), dan solvent-drop grinding (SDG) piperin-kuersetin (1:1) memperlihatkan peningkatan kelarutan relatif terhadap kelarutan larutan jenuh piperin tunggal dalam air suling bebas $\mathrm{CO}_{2}$. Pembentukan multikomponen piperin-kuersetin diduga dapat menyebabkan turunnya derajat kristalinitas senyawa. Hal ini menyebabkan terjadi penurunan titik leleh yang mengindikasikan energi kisi menjadi lebih rendah. Menurunnya derajat kristalinitas mengakibatkan peningkatan jumlah zat yang terlarut dalam pelarut. Penurunan ukuran partikel karena proses penggerusan pada pembuatan multikomponen piperin-kuersetin dengan metode solvent-drop grinding diduga juga dapat meningkatkan jumlah zat yang terlarut dalam pelarut.

\section{KESIMPULAN}

Hasil karakterisasi difraksi sinar-X, DSC, dan FTIR menunjukkan bahwa multikomponen kristal piperin-kuersetin dengan metode solvent-drop grinding dengan perbandingan ekuimol 1:1 tidak terbentuk. Pembentukan multikomponen kristal piperin-kuersetin dengan metode solventdrop grinding dengan perbandingan ekuimol 1:1 memberikan peningkatan kelarutan 1,39 kali dibandingkan piperin murni.

\section{UCAPAN TERIMA KASIH}

Ucapan terima disampaikan kepada LPPM Universitas Andalas yang telah mendanai penelitian ini melalui Program Penelitian Riset Dasar dengan nomor SK 559/UN16.R/XII/KPT/2020.

\section{DAFTAR PUSTAKA}

Atal, C. K., Dubey, R. K. and Singh, J. P. V. 1985. Biochemical basis of enhanced drug bioavailability by piperine: Evidence that piperine is a potent inhibitor of drug metabolism. Journal of Pharmacology and Experimental Therapeutics. 232(1), pp. 258-262.

Azajuddin et al. 2014. Role of herbal bioactives as a potential bioavailability enhancer for Active Pharmaceutical Ingredients. Fitoterapia. Elsevier B.V. 97, pp. 1-14.

Aziz, D. M., Hama, J. R. and Alam, S. M. 2015. Synthesising a novel derivatives of piperine from black pepper (Piper nigrum L.).Journal of Food Measurement and Characterization. Springer Verlag. 9(3), pp. 324-331. doi: 10.1007/s11694-015-9239-2.

Bhalekar, M. R. et al. 2017. Formulation of piperine solid lipid nanoparticles (SLN) for treatment of rheumatoid arthritis.Drug Development and Industrial Pharmacy. Taylor and Francis Ltd., 43(6), pp. 1003-1010. doi: 10.1080/03639045.2017.1291666.

Boots, A. W. et al. 2008. In vitro and ex vivo anti-inflammatory activity of quercetin in healthy volunteers.Nutrition, 24(7-8). pp. 703-710. doi: 10.1016/j.nut.2008.03.023. 
Ezawa, T. et al. 2018. Characterization of the Dissolution Behavior of Piperine/Cyclodextrins Inclusion Complexes.AAPS PharmSciTech. Springer New York LLC, 19(2), pp. 923-933. doi: 10.1208/s12249-017-0908-9.

Kesarwani, K. and Gupta, R. 2013. Bioavailability enhancers of herbal origin: An overview.Asian Pacific Journal of Tropical Biomedicine. Asian Pacific Tropical Biomedical Magazine, 3(4), pp. 253-266. doi: 10.1016/S2221-1691(13)60060-X.

Khajuria, A., Zutshi, U. and Bedi, K. L. 1998. Permeability characteristics of piperine on oral absorption - An active alkaloid from peppers and a bioavailability enhancer. Indian Journal of Experimental Biology, 36(1), pp. 46-50.

Kumar, A. et al. 2019. Fourier transform infrared spectroscopy: Data interpretation and applications in structure elucidation and analysis of small molecules and nanostructures, Data Processing Handbook for Complex Biological Data Sources. Elsevier Inc. doi: 10.1016/b978-0-12-816548-5.00006-x.

Kumar, S. et al. 2018. Role of Piperine in Chemoresistance. Role of Nutraceuticals in Cancer Chemosensitization. Academic Press, pp. 259-286. doi: 10.1016/B978-0-12-8123737.00013-9.

$\mathrm{Lu}$, J. and Rohani, S. 2009. Preparation and characterization of theophylline-nicotinamide cocrystal. Organic Process Research and Development, 13(6), pp. 1269-1275. doi: 10.1021/op900047r.

Mehta, A., Kaur, G. and Chintamaneni, M. 2012. Piperine and quercetine enhances antioxidant and hepatoprotective effect of curcumin in paracetamol induced oxidative stress'.

Miltonprabu, S. 2019. Quercetin: A Flavonol With Versatile Therapeutic Applications and Its Interactions With Other Drugs, Nonvitamin and Nonmineral Nutritional Supplements. Elsevier Inc. doi: 10.1016/b978-0-12-812491-8.00010-2.

Müller, U. 1994. Introduction to modern vibrational spectroscopy, J. Wiley', Berichte der Bunsengesellschaft für physikalische Chemie, 98(10), pp. 1347-1348. doi: 10.1002/bbpc. 19940981029.

Pachauri, M., Gupta, E. D. and Ghosh, P. C. 2015. Piperine loaded PEG-PLGA nanoparticles: Preparation, characterization and targeted delivery for adjuvant breast cancer chemotherapy. Journal of Drug Delivery Science and Technology. Editions de Sante, 29, pp. 269-282. doi: 10.1016/j.jddst.2015.08.009.

Ramos, F. A. et al. 2006. Antibacterial and antioxidant activities of quercetin oxidation products from yellow onion (Allium cepa) skin. Journal of Agricultural and Food Chemistry, 54(10), pp. 3551-3557. doi: 10.1021/jf060251c.

Rinwa, P., Machawal, L. and Kumar, A. 2012. Piperine potentiates the protective effect of quercetin against chronic unpredictable stress-induced cognitive dysfunction in mice', Alzheimer's \& Dementia. Elsevier Ltd, 8(4), pp. P198-P199. doi: 10.1016/j.jalz.2012.05.542.

Sari, Y. N., Zaini, E. and Ismed, F. 2019. Peningkatan Laju Disolusi Piperine dengan Pembentukan Multikomponen Kristal Menggunakan Asam Nikotinat. JSFK (Jurnal Sains Farmasi \& Klinis), 6(2), pp. 180-185. doi: 10.25077/JSFK.6.2.180-185.2019.

Setiabudi, A., Hardian, R. and Mudzakir, A. 2012. Karakterisasi Material; Prinsip dan Aplikasina dalam Penelitian Kimia.

Shaikh, J. et al. 2009. Nanoparticle encapsulation improves oral bioavailability of curcumin by at 
least 9-fold when compared to curcumin administered with piperine as absorption enhancer., European journal of pharmaceutical sciences : official journal of the European Federation for Pharmaceutical Sciences, 37(3-4), pp. 223-30. doi: 10.1016/j.ejps.2009.02.019.

Thenmozhi, K. and Yoo, Y. J. 2017. Enhanced solubility of piperine using hydrophilic carrierbased potent solid dispersion systems. Drug Development and Industrial Pharmacy. Taylor and Francis Ltd., 43(9), pp. 1501-1509. doi: 10.1080/03639045.2017.1321658.

Theses, G. and Dawn Marie Clarke, H. 2012. Scholar Commons Crystal Engineering of MultiComponent Crystal Forms: The Opportunities and Challenges in Design. Available at: http://scholarcommons.usf.edu/etdhttp://scholarcommons.usf.edu/etd/4013 (Accessed: 27 November 2019).

Veerareddy, P. R., Vobalaboina, V. and Nahid, A. 2004. Formulation and evaluation of oil-in-water emulsions of piperine in visceral leishmaniasis.', Die Pharmazie, 59(3), pp. 194-7.

Yusuf, M. et al. 2013. Preparation, characterization, in vivo and biochemical evaluation of brain targeted Piperine solid lipid nanoparticles in an experimentally induced Alzheimer's disease model. Journal of Drug Targeting, 21(3), pp. 300-311. doi: 10.3109/1061186X.2012.747529.

Zandi, K. et al. 2011. Antiviral activity of four types of bioflavonoid against dengue virus type2.Virology Journal, 8. doi: 10.1186/1743-422X-8-560. 